\title{
Microbial Growth in Shrimp Ponds as Influenced by Monosilicic and Polysilicic Acids
}

\section{Ruiping Zhang}

Beijing Plum Agrochemicals

\section{Elena Bocharnikova}

Institute Basic Biological Problems RAS

Vladimir Matichenkov ( $\nabla$ vmatichenkov@yandex.ru )

Institute Basic Biological Problems RAS https://orcid.org/0000-0003-2659-5295

\section{Research Article}

Keywords: bacteria, microbial ecology, monosilicic acid, polysilicic acids, silicon

Posted Date: September 21st, 2021

DOl: https://doi.org/10.21203/rs.3.rs-908767/v1

License: (c) (1) This work is licensed under a Creative Commons Attribution 4.0 International License. Read Full License

Version of Record: A version of this preprint was published at Silicon on January 18th, 2022. See the published version at https://doi.org/10.1007/s12633-021-01599-y. 


\section{Abstract}

In order to increase shrimp production and minimize detrimental environmental impacts of aquaculture, the maintenance and regulation of the growth and composition of phytoplankton communities and nutritional balance are critical. Silicon ( $\mathrm{Si}$ ) is an essential nutrient for diatoms and other types of microorganisms, but the information about the $\mathrm{Si}$ impact on their growth is extremely scarce. Monosilicic and polysilicic acids were tested in several shrimp cultivation systems in Jiangsu Province, China. In pond waters, the concentrations of monosilicic and polysilicic acids sharply reduced by $36-95 \%$ and $35-$ $75 \%$, accordingly, as compared with those in supply water sources. The microbial cell abundance was strongly dependent on monosilicic acid, while the correlation with polysilicic acid was absent. In laboratory experiments, monosilicic acid added to pond water or probiotic solution at 1 and $2 \mathrm{mM} \mathrm{Si} \mathrm{had}$ a significant positive effect on cell abundance. Over three days, the concentrations of monosilicic acid decreased by 81 to $91 \%$ in pond water and by 11 to $24 \%$ in probiotic solution. In probiotic solutions, the degree of polymerization of silicic acid was more intensive than that in shrimp pond waters. The data obtained demonstrates the importance of systematic studies related to the functions of Si in shrimp aquaculture.

\section{Introduction}

Shrimp farming production is one of the fastest-growing segments of the world agriculture with a forecast of the compound annual growth rate in the period 2017-2021 being 4.8 to $5.4 \%$ (Anderson et al. $2016 ; 2019)$. Undoubtedly, shrimp farming management should be based on a systems approach including the application of different materials to provide high productivity and quality and minimize negative impact on the environment (Ray and Lotz, 2017; Sarkar et al. 2019). To develop an efficient management strategy, understanding of the factors that maintain and control shrimp production is required. In the aquaculture system, the microbial community plays a significant role in providing additional feed, enhancing nutrient utilization efficiency, reducing anoxic conditions, and minimizing environmental impacts (Denev et al. 2009).

Silicon (Si) is the second abundant element after oxygen on our planet. The role and functions of $\mathrm{Si}$ in plant physiology, veterinary, and medicine have been investigated for more than 200 years (Chepeleva et al. 2018; Szacawa et al. 2019). Much Si-related research was conducted for plants and soil-plant system (Snyder et al. 2016). Over the last decade, Si has been recognized as an essential trace element in the metabolism of higher plants and animals (Michalak \& Chojnacka 2018, Peris-Felipo et al. 2020). In plant biology and agriculture, Si has been declared a beneficial element being particularly important for the immune system induction in response to abiotic and biotic stresses (Guerriero et al. 2016). Improved Si nutrition has a multi-effect on plant growth and cell functioning (Ma et al. 2001). Silicon-mediated impacts like sugar formation, DNA stability, transport regulation (activated Fe, B, K, Ca transport and reduced that of $\mathrm{Cd}, \mathrm{Hg}, \mathrm{As}, \mathrm{Na}$ ) have been reported as a result of Si addition (Bocharnikova et al. 2014; Hernandez-Apaolaza 2014, Adrees et al. 2015). 
Several forms of $\mathrm{Si}$ are commonly presented in natural water: monosilicic acid, polysilicic acid (oligomers and polymers with large number of Si atoms), and organo-silicon compounds (ller 1979; Dietzel 2002; Bocharnikova and Matichenkov 2012). However, plants uptake Si only in the form of monosilicic acid (Ma et al. 2001). Although polysilicic acid is soluble, it is not absorbed by plants (Bocharnikova and Matichenkov 2012).

In the aquatic system, $\mathrm{Si}$ is recognized as a key nutrient for diatoms and some sponges. It is also consumed by radiolarians, silicoflagellates, several species of choanoflagellates, and some picocyanobacteria (Tréguer and Rocha 2013). Diatoms have silicified frustules and require a high level of $\mathrm{Si}$ in the form of monosilicic acid (Leynaert et al. 2009). Diatom populations are responsible for $\sim 50 \%$ of marine net primary production and provide the base of marine food chains (Nelson 1995). The predominance of diatoms in shrimp ponds is highly desired because of nutritional properties. In the presence of diatoms, biochemical composition of shrimp is characterized by higher proteins, lipids, essential amino acids and unsaturated fatty acids (Brito et al. 2016; de Abreu et al. 2019). Silicon fertilization is a common approach to encourage diatom growth (Martins et al. 2016; Llario et al. 2019).

Among serious problems faced by shrimp farming are infectious diseases and environmental deterioration. Probiotics are successfully used to overcome these challenges (Lakshmi et al. 2013; van Hai \& Fotedar 2010). Probiotics improve growth performance, stimulate immune responses, enhance disease resistance of shrimp, inhibit growth of pathogens as well as improve water quality parameters (Hoseinifar et al. 2018). Probiotics usually include different bacteria, bacteriophages, microalgae, and yeast species (Llewellyn et al. 2014; Wang et al. 2019) There are monostrain, multistrain and multispecies probiotics (Das et al. 2017; Van Doan et al. 2017). Information about the effect of Si on the metabolism of microorganisms other than diatoms and its impact on their growth is extremely scarce (Wainwright et al. 1997; Hurst et al. 2007).

Knowledge about the relationship between $\mathrm{Si}$ application rates and mono- and polysilicic acid concentrations in pond water, and how fast Si disappears from water as well as the relationship between mono- and polysilicic acid concentrations and microbial growth is critical to manage the microbial community. The aim of this study was to evaluate the concentrations of monosilicic and polysilicic acids in shrimp ponds and to determine the effect of monosilicic acid on microbial growth in pond water and in a probiotic solution.

\section{Materials And Methods}

Field tests

Water samples were collected on 3 shrimp farms located in Jiangsu Province, China, in April. The first

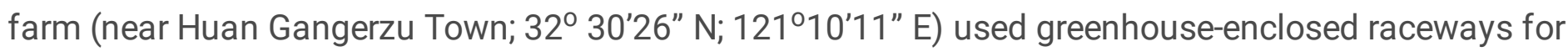
intensive shrimp production. Fresh groundwater was directly pumped into separated ponds under a 
greenhouse, each individual pond was $6 \times 50 \mathrm{~m}$ in size. The shrimp age was 2 months. Water was sampled from well, 6 ponds, and a small creek filled with effluents from ponds.

The second shrimp farm (near Changsha City; $32^{\circ} 23^{\prime} 31^{\prime \prime} \mathrm{N} ; 1^{12} 1^{\circ} 18^{\prime} 09^{\prime \prime} \mathrm{E}$ ) had a system of open ponds (100 $\times 50$ m each), filled with unsalted water from a local canal. Thee shrimps were 2 months old. Water was sampled from the canal and 6 ponds.

The third shrimp farm (near Yangkou Town; $32^{\circ} 35^{\prime} 44^{\prime \prime} \mathrm{N}, 120^{\circ} 59^{\prime} 09^{\prime \prime} \mathrm{E}$ ) took water directly from the Yellow Sea. Open ponds were 250 × $60 \mathrm{~m}$ each. Water was collected from 6 ponds, and a canal supplied water to the ponds. The shrimps were 1 month old.

Samples were collected in triplicate in $100 \mathrm{~mL}$ plastic bottles early in the morning and were immediately transported to a laboratory to determine monosilicic acid, polysilicic acid, $\mathrm{pH}$ and microbial cell abundance.

The $\mathrm{pH}$ was analyzed on an lon Meter PHS-3e (MRC, China). The concentration of monosilicic acid was determined using the modified molybdenum blue method (Mullin and Riley, 1955) with a spectrophotometer V5800 XZBELEC (China). This method tests Si only in the form of monosilicic acid, without interference from phosphorus.

To analyze polysilicic acid, $2 \mathrm{~g}$ of $\mathrm{NaOH}$ was added to $20 \mathrm{~mL}$ of centrifuged water and kept in a refrigerator at $+4^{\circ} \mathrm{C}$ for 2 weeks (Matichenkov et al. 1997). During this time all polymers of silicic acid are transformed into monomers. After that monosilicic acid was determined as described above. The concentration of polysilicic acid was calculated by the following formula:

$S i_{\text {poly }}=S i_{\text {total }}-S i_{\text {mono, }}$

where $\mathrm{Si}_{\text {total }}$ is the concentration of monosilicic acid determined after depolymerization;

$\mathrm{Si}_{\text {mono }}$ is the concentration of monosilicic acid determined before depolymerization.

Microbial abundance (cells $\mathrm{mL}^{-1}$ ) was estimated on the day of sampling by binocular biological microscope (ML10, Guangzhou Mingmei, China) according to the method proposed by Newell and Newell (2006). The same method was used to calculate the cell density in the laboratory experiment.

Laboratory experiment

A laboratory experiment was conducted with collected farm water summarized samples and 3 commercial probiotics used in shrimp farming: dry probiotics "Ecopro" and "Ecopro Cold" (Ecomicrobial Co, USA) and liquid probiotic "HeJunMei" (Jiangsu Aijiafuru Soil Remediation Co, China). In dry and liquid probiotics, the amounts of bacteria and yeast spores were not less than $1 \times 10^{12}$ and $1 \times 10^{10}$ cells $\mathrm{kg}^{-1}$, respectively. 
To activate dry probiotics, $1 \mathrm{~g}$ of probiotic was mixed with $1 \mathrm{~L}$ of sterilized distilled water (DW) and kept at $+24^{\circ} \mathrm{C}$ for $24 \mathrm{~h}$. The liquid probiotic was diluted $1: 10$.

One liter of nutrient solution was prepared with $\mathrm{K}_{2} \mathrm{HPO}_{4} 3.125 \mathrm{~g} ; \mathrm{KH}_{2} \mathrm{PO}_{4} 3.125 \mathrm{~g} ;\left(\mathrm{NH}_{4}\right)_{2} \mathrm{HPO}_{4} 3.125 \mathrm{~g}$; $\mathrm{MgSO}_{4} .7 \mathrm{H}_{2} \mathrm{O} 0.25 \mathrm{~g} ; \mathrm{FeSO}_{4} .7 \mathrm{H}_{2} \mathrm{O} 0.0125 \mathrm{~g} ; \mathrm{MnSO}_{4} .7 \mathrm{H}_{2} \mathrm{O} 0.00875 \mathrm{~g}$ and sucrose $12.5 \mathrm{~g}$ (Vitullo et al. 2012). Eighty (80) $\mathrm{mL}$ of this nutrient solution was added to each flask. Ten (10) $\mathrm{mL}$ of pond water collected on the day of sampling, probiotic solution or DW was added to the flasks. Considering that Farm 3 used sea water, $\mathrm{NaCl}\left(35 \mathrm{~g} \mathrm{~L}^{-1}\right)$ was added to flasks with pond water from Farm 3 . Then $10 \mathrm{~mL}$ of DW or monosilicic acid solution at 10 and $20 \mathrm{mM} \mathrm{Si}$ was added to reach the Si concentrations of 0,1 and $2 \mathrm{mM}$. Monosilicic acid solutions were prepared from concentrated monosilicic acid (Fisher Scientific, CAS-No 7699-41-4). The $\mathrm{pH}$ in each flask was adjusted to 7 by adding $0.1 \mathrm{M} \mathrm{HCl}$ or $0.1 \mathrm{M} \mathrm{NaCl}$.

Flasks were kept in a climatic chamber at $24 \pm 1^{\circ} \mathrm{C}$. The light/night regime was $12 / 12$ hours with light intensity $600 \mu \mathrm{mol}$ photons $\mathrm{M}^{-2} \mathrm{~s}^{-1}$. Flasks were aerated twice a day for $1 \mathrm{~h}$ (morning and evening). After 3 days, the concentration of monosilicic acid and the density of microorganisms were determined using the method described above.

Each treatment and each analysis were conducted in triplicate. All data obtained was subjected to a statistical analysis based on comparative methods using Duncan's multiple range tests for mean separation at the $5 \%$ level of significance (Duncan 1957).

\section{Results}

The $\mathrm{pH}$, concentration of mono- and poly-silicic acids, and density of microorganisms in tested solutions are presented in Table 1. Monosilicic acid in water supplied to shrimp ponds differed greatly among farms, from 49.3 to $517.0 \mu \mathrm{M} \mathrm{Si}$, with a higher value in fresh underground water (Farm 1) and minimum value in coastal sea water (Farm 3). Although the maximum polysilicic acid also was in the fresh underground water, its proportion increased: Farm $1<$ Farm $2<$ Farm 3 and accounted for 3.1; 10.0; and $16.6 \%$, respectively.

Water was pumped to shrimp pond daily on all farms. In ponds, the concentrations of monosilicic acid were remarkably lower as compared with incoming water: by 26.3 times ( 517.0 vs $19.6 \mu \mathrm{M} \mathrm{Si}), 6.4$ times (100.0 vs $15.6 \mu \mathrm{M} \mathrm{Si}$ ), and 2.8 times (49.3 vs $17.3 \mu \mathrm{M} \mathrm{Si}$ ), respectively on Farm 1, Farm 2, and Farm 3. The concentrations of polysilicic acid decreased as well, but not as significantly.

The cell abundance in ponds of Farm 1 was higher than in others, probably due to more intensive farming system. However, the microbial densities differed, sometimes significantly, between ponds of each farm. For example, on Farm 1, the cell numbers ranged between $2.4 \pm 0.1$ and $3.9 \pm 0.2 \times 10^{5} \mathrm{~mL}^{-1}$, while on Farm 2 and Farm 3 the cell numbers ranged from $1.1 \pm 0.1$ to $1.6 \pm 0.2 \times 10^{5} \mathrm{~mL}^{-1}$ and from $1.4 \pm 0.2$ to $2.0 \pm 0.2 \times 10^{5} \mathrm{~mL}^{-1}$, respectively. 
The numbers of microbial cells and soluble forms of $\mathrm{Si}$ in the laboratory test are presented in Table 2. Supplementation of monosilicic acid significantly increased the microbial density, up to 60 and $33 \%$ in pond water and probiotic solution, respectively.

Over 3 days, the concentration of monosilicic acid decreased in all microorganism-containing solutions in comparison with the corresponding sterile solutions. Remarkable reductions in monosilicic acid were detected in all pond water samples, whereas probiotic solutions demonstrated much smaller changes.

Initial silicic acid contained $\mathrm{NaOH}$ to prevent polymerization; therefore, were no polymers. Since in the experiment the $\mathrm{pH}$ was 7 , the polysilicic acid formation proceeded in both sterile and nonsterile solutions. The process of polymerization was more intense in pond water and especially in probiotic solutions. The polysilicic acid concentration reached up to $230 \pm 21 \mathrm{mg} \mathrm{L}^{-1} \mathrm{Si}$ in liquid probiotic as compared to $10.5 \pm$ $0.3 \mathrm{mg} \mathrm{L}^{-1} \mathrm{Si}$ in the corresponding sterile solution.

\section{Discussion}

In the experiment, the concentrations of dissolved Si (DSi) (monosilicic acid + polysilicic acid) in supply water sources were $533.1 \mu \mathrm{mol}$ (groundwater, Farm 1), $110.0 \mu \mathrm{mol}$ (fresh water canal, Farm 2) and 57.53 $\mu \mathrm{mol}$ (sea water, Farm 3). This data is consistent with reported DSi concentrations in groundwater (Khan et al. 2015), surface terrestrial waters (Zhang et al. 2015), and ocean water (Zhao et al. 2000; Wei et al. 2015).

In tested shrimp ponds, DSi ranged from 14.0 to $60.7 \mu \mathrm{M}$ Si on Farm 1, from 17.8 to $23.5 \mu \mathrm{M}$ Si on Farm 2 and from 19.7 to $26.4 \mu \mathrm{M}$ Si on Farm 3 which corresponds to the available data. For example, DSi in low salinity shrimp ponds in Alabama ranges between 3.4 and $196 \mu \mathrm{M} \mathrm{Si}$ with an average of $37.0 \mu \mathrm{M}$ (Prapaiwong and Boyd 2014). It is important to note that we observed very fast reductions in pond water $\mathrm{Si}$, in spite of daily water exchange. The monosilicic acid concentration decreased more than the polysilicic acid (Table 3). It is well known that higher plants take up Si only in the form of monosilicic acid. Perhaps algae, being phototrophic organisms like higher plants, have the same mode of Si uptake. With decreasing monosilicic acid, equilibrium between soluble forms of Si shifts, resulting in acceleration of depolymerization, which is typical for the systems with low concentrations of monosilicic acid, in turn leading to decreasing polysilicic acid (Iler 1979).

The correlation coefficients between soluble forms of Si and cell abundance evidence that the number of microorganisms in ponds correlates positively with monosilicic acid $(R=0.80-0.84)$ (Table 4). There was no correlation between cell abundance and polysilicic acid. Therefore, unlike polysilicic acid, monosilicic acid is an essential factor in the regulation of microbial growth in the shrimp pond.

The laboratory experiment has shown that monosilicic acid affected beneficially microbial population in pond water and probiotics solution (Table 2). In pond water, Si may be consumed mainly by different algae species, including diatoms. The tested probiotics contained only bacteria having less need for $\mathrm{Si}$, though additional Si benefitted their growth as well. The increase in polysilicic acid with the addition of 
monosilicic acid could be the result of polymerization (Table 2). Monosilicic acid can be physically adsorbed on the cell wall leading to initiation of the polymerization process (Matichenkov et al. 2001). The formation of polymers was higher in probiotic solutions. Although a significance of this process in shrimp cultivation is unknown, Si polymers generally possess high adsorption properties to organic and inorganic molecules (Parida et al. 2006; Xia et al. 2008). Thus, new formed silica-gel (polymerized silicic acid) may adsorb organic compounds and nutrients promoting attraction of microorganisms and floc formation. This hypothesis requires further confirmation.

As is well known, diatoms require high level of DSi for growth (Sun et al. 2013; Tantanasarit et al. 2013; Matsumoto et al. 2017). Minimum DSi required for diatom growth was shown to be $0.1 \mathrm{mg} \mathrm{L}^{-1}(3.57 \mu \mathrm{M}$ Si) (Reynolds 2006). Early research reported that the monosilicic acid concentrations of 8.1-81.0 $\mu \mathrm{M} \mathrm{Si}$ benefit the cultivation of diatoms (Mast and Pace 1937). Soluble Si at $714 \mu \mathrm{M}$ stimulated respiration of diatoms (Lewin 1955). As recently shown, suitable Si concentration in a growth medium for diatoms amounts to $470 \mu \mathrm{M}$ as $\mathrm{Na}_{2} \mathrm{SiO}_{3} \star 5 \mathrm{H}_{2} \mathrm{O}$ (Ali et al. 2017). Optimal Si concentrations for diatoms depend on the species, as well as the content of other elements. For example, Adams and Bugbee (2014) found that the maximum dry mass density of diatoms (Chaetoceros gracilis) was observed at the Si concentrations of $200-400 \mu \mathrm{M}$ and $600-800 \mu \mathrm{M}$, respectively in highly salted water (400 mM Na) and low salted water $(50 \mathrm{mM} \mathrm{Na})$.

With decreasing the Si concentration, other phytoplanktonic algae that do not need so much Si can replace diatoms (Boyd 2014). Among undesirable algae species, blue-green algae are of particular concern. Blooms of blue-green algae cause a lack of dissolved oxygen, off-flavors problems, and toxin formation, thus deteriorating water quality and declining shrimp productivity (Jescovitch et al. 2018). Evidently, the abundance of silicic acid is an essential requirement to achieve desirable diatom domination in algal communities. However, no systematic studies have been conducted showing the $\mathrm{Si}$ limitation and influence of its addition on shrimp production.

The obtained data has demonstrated that all tested shrimp ponds were characterized by extremely low concentrations of monosilicic acid, while the supply waters originally were high in DSi. Monosilicic acid applied to shrimp pond water or probiotic solution significantly increased the microbial cell abundance. It is important to distinguish monomeric and polymeric forms of DSi, because these substances affect microbial population in aquaculture in different ways.

\section{Declarations}

\section{Funding}

This study was supported by the Ministry of Science and Higher Education of RF, theme \#AAAA-A17117030110137-5 and \#AAAA-A17-117030110139-9. This research also has been funded by Jiangsu Province's "provincial entrepreneurship and innovation talent plan" and Nantong's "Jianghai talent plan".

\section{Conflict of interest}


Dr. Ruiping Zhang declares that she has no conflict of interest.

Dr. Elena Bocharnikova declares that she has no conflict of interest.

Prof. Vladimir Matichenkov declares that he has no conflict of interest.

\section{Availability of data and materials}

All data availability statement is present within the text of the manuscript

\section{Code availability}

Not available

\section{Authors' contributions}

Dr. Ruiping Zhang participate in sample collection, analysis and manuscript writing, Dr. Elena Bocharnikova is participated in the analysis, laboratory test and manuscript writing, Prof. Vladimir Matichenkov is participated in the sample collection, laboratory experiments and manuscript preparation.

\section{Ethics approval}

This article does not contain any studies with human participants or animals performed by any of the authors

\section{Consent to participate}

All authors are agreed to be listed as authors in current version of manuscript.

\section{Consent for publication}

All authors are agreed for publication of tis manuscript in the Applied Microbiology and Biotechnology.

\section{Conflict of Interest}

There is no conflict of interest

\section{Acknowledgements}

This study was supported by the Ministry of Science and Higher Education of RF, theme \#AAAA-A17117030110137-5 and \#AAAA-A17-117030110139-9. This research also has been funded by Jiangsu Province's "provincial entrepreneurship and innovation talent plan" and Nantong's "Jianghai talent plan".

\section{References}

1. Adams C, Bugbee B (2014) Enhancing lipid production of the marine diatom Chaetoceros gracilis: synergistic interactions of sodium chloride and silicon. J Appl Phycol26(3):1351- 
https://doi.org/10.1007/s10811-013-0156-7

2. Adrees $M$, Ali S, Rizwan M, Zia-ur-Rehman M., Ibrahim M, Abbas F, Farid M, Qayyum M, Irshad M (2015) Mechanisms of silicon-mediated alleviation of heavy metal toxicity in plants: a review. Ecotox Environ Safe 119:186- https://doi.org/10.1016/j.ecoenv.2015.05.011

3. Ali S, Radzun K, Ahmad N (2017) Isolation and adaptation of diatoms in a new formulated enriched medium. Pertanika J Sci Technol 25:21-

4. Anderson J, Valderrama D, Jory D (2016) Shrimp production review. Global Aquaculture Alliance: Presentation Global Aquaculture Production Data and Analysis, p 1-50

5. Anderson JL, Valderrama D, Jory D (2019) Shrimp production review. Global Aquaculture Alliance: Presentation Global Aquaculture Production Data and Analysis. https://www.aquaculturealliance.org/advocate/goal-2019-global-shrimp-production-review/

6. Bocharnikova EA, Matichenkov VV (2012) Influence of plant associations on the silicon cycle in the soil-plant ecosystem. Appl Ecol Environ Res10(4):547-

7. Bocharnikova EA, Pakhnenko EP, Matychenkov VV, Matychenkov IV (2014) The effect of optimization of silicon nutrition on the stability of barley DNA. Moscow Univ Soil Sci Bull 69(2):84https://doi.org/10.3103/S0147687414020033

8. Boyd CE (2014) Silicon, diatoms in aquaculture. Global Aquaculture Advocate May/June, 38-39

9. Brito LO, dos Santos IGS, de Abreu JL, de Araújo MT, Severi W, Gàlvez AO (2016) Effect of the addition of diatoms (Navicula spp.) and rotifers (Brachionus plicatilis) on water quality and growth of the Litopenaeus vannamei postlarvae reared in a biofoc system. Aquac Res 47:3990-3997 https://doi.org/10.1111/ are.12849

10. Chepeleva E, Kozyr K, Zubarev D, Kudriashov A, Kretov E, Vasilieva M, ... Sergeevichev D (2018) Blood plasma cytokines releasing after implantation of self-expanding nitinol stents modified with silicon in experimental animals. AIP Conf Proc2051(1):020048 https://doi.org/10.1063/1.5083291

11. Das S, Mondal K, Haque S (2017) A review on application of probiotic, prebiotic and synbiotic for sustainable development of aquaculture. J Entomol 5(2):422-

12. de Abreu JL, Brito LO, de Lima PC, Silva SM, Severi W, Gálvez AO (2019) Effects of addition of Navicula sp. (diatom) in different densities to postlarvae of shrimp Litopenaeus vannamei reared in a BFT system: Growth, survival, productivity and fatty acid profile. Aquaculture50(8):2231https://doi.org/10.1111/are.14104

13. Denev S, Beev G, Staykov Y, Moutafchieva R (2009) Microbial ecology of the gastrointestinal tract of fish and the potential application of probiotics and prebiotics in finfish aquaculture. Int Aquat Res1:1- https://doi.org/10.1111/j.1749-7345.2005.tb00390.x

14. Dietzel M (2002) Interaction of polysilicic and monosilicic acid with mineral surfaces. In: Stober I, Bucher K (eds) Water-rock interaction. Springer, Dordrecht, p. 207-235.

15. Duncan DB (1957) Multiple range tests for correlated and heteroscedastic means. Biometrics 13(2):164- DOI: 10.2307/2527799 
16. Guerriero G, Hausman JF, Legay S (2016) Silicon and the plant extracellular matrix. Plant Sci.7:463. https://doi.org/10.3389/fpls.2016.00463

17. Hernandez-Apaolaza L (2014) Can silicon partially alleviate micronutrient deficiency in plants? a review. Planta 240(3) :447- https://doi.org/10.1007/s00425-014-2119-x

18. Hoseinifar SH, Sun YZ, Wang A, Zhou Z (2018) Probiotics as means of diseases control in aquaculture, a review of current knowledge and future perspectives. Front Microbiol9: https://doi.org/10.3389/fmicb.2018.02429

19. Hurst CJ, Crawford RL, Garland JL, Lipson DA (2007) Manual of environmental microbiology. ASM Press, Washington

20. Iler RK (1979) The Chemistry of Silica. Wiley, New York.

21. Jescovitch LN, Ullman C, Rhodes M, Davis DA (2018) Effects of different feed management treatments on water quality for Pacific white shrimp Litopenaeus vannamei. Aquac Res49(1) :526https://doi.org/10.1111/are.13483

22. Khan A, Umar R, Khan HH (2015) Significance of silica in identifying the processes affecting groundwater chemistry in parts of Kali watershed, Central Ganga Plain, India. Appl Water Sci5(1) :65- https://doi.org/10.1007/s13201-014-0164-z

23. Lakshmi B, Viswanath B, Sai Gopal DV (2013) Probiotics as antiviral agents in shrimp aquaculture. J Pathog 424123 https://doi.org/10.1155/2013\%2F424123

24. Lewin JC (1955) Silicon metabolism in diatoms: III. Respiration and silicon uptake in Navicula pelliculosa. J Gen Physiol 39(1):1-10. doi:10.1085/jgp.39.1.1

25. Leynaert A, Longphuirt SN, Claquin P, Chauvaud L, Ragueneau O (2009) No limit? The multiphasic uptake of silicic acid by benthic diatoms. Limnol Oceanogr 54(2):571-

26. Llario F, Rodilla M, Escrivá J, Falco S, Sebastiá-Frasquet MT (2019) Phytoplankton evolution during the creation of a biofloc system for shrimp culture. Int J Environ Sci Te16(1):211https://doi.org/10.1007/s13762-018-1655-5

27. Llewellyn MS, Boutin S, Hoseinifar SH, Derome N (2014) Teleost microbiomes: the state of the art in their characterization, manipulation and importance in aquaculture and fisheries. Front Microbiol5: doi: $10.3389 /$ fmicb.2014.00207

28. Ma JF, Miyake Y, Takahashi E (2001) Silicon as a beneficial element for crop plants. In: Datnoff, L.E., Snyder, G.H., Korndorfer, G.H. (eds) Silicon in agriculture. Elsevier, p 17-

29. Martins TG, Odebrecht C, Jensen LV, D'Oca MG, Wasielesky JW (2016) The contribution of diatoms to bioflocs lipid content and the performance of juvenile Litopenaeus vannamei (Boone, 1931) in a BFT culture system. Aquac Res47(4) :1315- https://doi.org/10.1111/are.12592

30. Mast SO, Pace DM (1937) The effect of silicon on growth and respiration in Chilomonas paramecium. Cell. Physiol.10(1):1-13. https://doi.org/10.1002/jcp.1030100102

31. Matichenkov VV, Ammosova YM, Bocharnikova EA (1997) The method for determining plantavailable silicon in soil. Agrochemistry [Rus] (1) : 76- 
32. Matichenkov VV, Korenevsky AA, Beveridge TJ (2001) Adsorption of soluble silicon compounds by Pseudomonas Aeruginosa. In: Proc. $11^{\text {th }}$ Annual V. M. Goldschmidt Conference. Hot Springs, Virginia, p 3831

33. Matsumoto M, Nojima D, Nonoyama T, Ikeda K, Maeda Y, Yoshino T, Tanaka T (2017) Outdoor cultivation of marine diatoms for year-round production of biofuels. Mar Drugs15(4): https://dx.doi.org/10.3390\%2Fmd15040094

34. Michalak I, Chojnacka K (2018) Fluorine and silicon as essential and toxic trace elements. In: Chojnacka, K., Saeid, A. (Eds) Recent advances in trace elements, John Wiley \& Sons, p 207-

35. Mullin JB, Riley JP (1955) The colorimetric determination of silicate with special reference to sea and natural waters. Anal Chim Acta 12:162-176. https://doi.org/10.1016/S0003-2670(00)87825-3

36. Nelson DM, Tréguer P, Brzezinski MA, Leynaert A, Quéguiner B (1995) Production and dissolution of biogenic silica in the ocean: revised global estimates, comparison with regional data and relationship to biogenic sedimentation. Global Biogeochem. Cycles 9 (3) :359-

37. Newell GE, Newell RC (2006) Marine plankton (a practical guideto ecology, methodology, and taxonomy). Oxford University Press, London.

38. Parida SK, Dash S, Patel S, Mishra BK (2006) Adsorption of organic molecules on silica surface. Adv Colloid Interface Sci121(1-3) :77-

39. Peris-Felipo FJ, Benavent-Gil Y, Hernández-Apaolaza L (2020) Silicon beneficial effects on yield, fruit quality and shelf-life of strawberries grown in different culture substrates under different iron status. Plant Physiol Biochem 152:23- https://doi.org/10.1016/j.plaphy.2020.04.026

40. Prapaiwong N, Boyd CE (2014) Trace elements in waters of inland, low-salinity shrimp ponds in Alabama. Aquac Res45(2), 327- https://doi.org/10.1111/j.1365-2109.2012.03230.x

41. Ray AJ, Lotz JM (2017) Comparing salinities of 10, 20, and 30\%o in intensive, commercial-scale biofloc shrimp (Litopenaeus vannamei) production systems. Aquaculture476:29https://doi.org/10.1016/j.aquaculture.2017.03.047

42. Reynolds CS (2006) Ecology of phytoplankton. Cambridge University Press, Cambridge, USA

43. Sarkar AK, Islam MN, Ansary FH (2019) Some aspects of shrimp farming systems and shrimp production management: Bangladesh perspective. J Biodivers Conserv Bioresour Manag5(2) :93https://www.researchgate.net/deref/https\%3A\%2F\%2Fdoi.org\%2F10.3329\%2Fjbcbm.v5i2.449

44. Snyder GH, Matichenkov VV, Datnoff LE (2016) Silicon. In: Barker AV, Pilbeam DJ (eds) Handbook of plant nutrition, CRC Press, p 567-584.

45. Sun X, Andersson PS, Humborg C, Pastuszak M, Mörth CM (2013) Silicon isotope enrichment in diatoms during nutrient-limited blooms in a eutrophied river system. J Geochem Explor132:173https://doi.org/10.1016/j.gexplo.2013.06.014

46. Szacawa E, Dudek K, Bederska-Łojewska D, Lisiecka U, Bednarek D, Pieszka M (2019) The effect of silicon dioxide nanoparticles as feed additive on health condition and immunological parameters of calves. The Animal Biology 21(2): 
47. Tantanasarit C, Englande AJ, Babel S (2013) Nitrogen, phosphorus and silicon uptake kinetics by marine diatom Chaetoceros calcitrans under high nutrient concentrations. J Exp Mar Biol Ecol446:67- https://doi.org/10.1016/j.jembe.2013.05.004

48. Tréguer P, De La Rocha CL (2013) The world ocean silica cycle. Annu Rev Mar Sci 5:477-501. https://doi.org/10.1146/annurev-marine-121211-172346

49. Van Doan H, Hoseinifar SH, Dawood MA, Chitmanat C, Tayyamath K (2017) Effects of Cordyceps militarisspent mushroom substrate and Lactobacillus plantarum on mucosal, serum immunology and growth performance of Nile tilapia (Oreochromis niloticus). Fish Shellfish Immun 70:87-94. doi: 10.1016/j.fsi.2017.09.002

50. van Hai N, Fotedar R (2010) A review of probiotics in shrimp aquaculture. J Appl Aquaculture22(3) :251- DOI: 10.1080/10454438.2010.500597

51. Vitullo D, Di Pietro A, Romano A, Lanzotti V, Lima G (2012) Role of new bacterial surfactants in the antifungal interaction between Bacillus amyloliquefaciens and Fusarium oxysporum. Plant Pathol 61(4) :689- DOI: 10.1111/j.1365-3059.2011.02561.x

52. Wainwright M, Al-Wajeeh K, Grayston SJ (1997) Effect of silicic acid and other silicon compounds on fungal growth in oligotrophic and nutrient-rich media. Mycol Res 101(8) :933https://doi.org/10.1017/S0953756297003560

53. Wang A, Ran C, Wang Y, Zhang Z, Ding Q, Yang Y, Olsen R, Ringo E, Bindelle J, Zhou Z (2019) Use of probiotics in aquaculture of China-a review of the past decade. Fish Shellfish Immun86:734https://doi.org/10.1016/j.fsi.2018.12.026

54. Wei Q, Yao Q, Wang B, Wang H, Yu Z (2015) Long-term variation of nutrients in the southern Yellow Sea. Cont Shelf Res111:184- https://doi.org/10.1016/j.csr.2015.08.003

55. Xia ZZ, Chen CJ, Kiplagat JK, Wang RZ, Hu JQ (2008) Adsorption equilibrium of water on silica gel. J Chem Eng Data53(10) :2462-2465. https://doi.org/10.1021/je800019u

56. Zhang Q, Tao Z, Gao Q, Ma Z (2015) A review of the biogeochemical cycles of dissolved silicon in rivers. Advances in Earth Science30(1):50-

57. Zhao W, Jiao N, Zhao Z (2000) Distribution and variation of the nutrient in the Yantai Sisihili bay cultivated water. Mar Sci 24(4) :31-

\section{Tables}


Table 1

Mono- and poly-silicic acids, $\mathrm{pH}$ and abundance of microbial cells in waters sampled on shrimp farms.

\begin{tabular}{|c|c|c|c|c|}
\hline \multirow{2}{*}{$\begin{array}{l}\text { Sample, } \\
\text { pond \# }\end{array}$} & \multirow[t]{2}{*}{$\mathrm{pH}$} & Monosilicic acid & Polysilicic acid & \multirow[t]{2}{*}{$x 10^{5}$ cells $\mathrm{mL}^{-1}$} \\
\hline & & \multicolumn{2}{|c|}{$\longrightarrow$ Si, $\mu \mathrm{M} \longrightarrow$} & \\
\hline \multicolumn{5}{|l|}{ Farm 1} \\
\hline Supply water & $7.27 \pm 0.11$ & $517.0 \pm 25.4$ & $16.1 \pm 0.3$ & $\mathrm{n} / \mathrm{d}$ \\
\hline 1 & $7.36 \pm 0.13$ & $8.6 \pm 0.4$ & $5.4 \pm 0.2$ & $2.5 \pm 0.2$ \\
\hline 2 & $7.50 \pm 0.12$ & $52.1 \pm 2.4$ & $8.6 \pm 0.2$ & $3.9 \pm 0.2$ \\
\hline 3 & $8.44 \pm 0.13$ & $13.2 \pm 1.3$ & $4.3 \pm 0.1$ & $2.4 \pm 0.1$ \\
\hline 4 & $7.36 \pm 0.13$ & $17.5 \pm 1.5$ & $3.9 \pm 0.1$ & $3.2 \pm 0.2$ \\
\hline 5 & $7.58 \pm 0.11$ & $13.5 \pm 1.4$ & $8.6 \pm 0.2$ & $3.4 \pm 0.3$ \\
\hline 6 & $8.25 \pm 0.11$ & $12.5 \pm 0.5$ & $9.3 \pm 0.3$ & $2.6 \pm 0.1$ \\
\hline Average for ponds & 7.74 & $19.6 \pm 2.1$ & $6.7 \pm 0.2$ & 3.1 \\
\hline \multicolumn{5}{|l|}{ Farm 2} \\
\hline Supply water & $8.43 \pm 0.12$ & $100.0 \pm 15.4$ & $10.0 \pm 0.3$ & $0.2 \pm 0.1$ \\
\hline 1 & $8.65 \pm 0.11$ & $20.0 \pm 1.1$ & $3.5 \pm 0.2$ & $1.6 \pm 0.2$ \\
\hline 2 & $8.58 \pm 0.10$ & $15.4 \pm 1.2$ & $4.3 \pm 0.2$ & $1.4 \pm 0.2$ \\
\hline 3 & $8.55 \pm 0.10$ & $12.8 \pm 1.0$ & $5.0 \pm 0.2$ & $1.1 \pm 0.3$ \\
\hline 4 & $8.65 \pm 0.12$ & $19.3 \pm 1.3$ & $4.3 \pm 0.1$ & $1.3 \pm 0.2$ \\
\hline 5 & $8.53 \pm 0.12$ & $15.0 \pm 1.2$ & $5.4 \pm 0.2$ & $1.2 \pm 0.2$ \\
\hline 6 & $8.43 \pm 0.11$ & $11.4 \pm 1.1$ & $6.4 \pm 0.2$ & $1.1 \pm 0.1$ \\
\hline Average for ponds & 8.56 & $15.6 \pm 1.4$ & $4.8 \pm 0.1$ & 1.25 \\
\hline \multicolumn{5}{|l|}{ Farm 3} \\
\hline Supply water & $8.32 \pm 0.11$ & $49.3 \pm 3.5$ & $8.2 \pm 0.3$ & $0.1 \pm 0.1$ \\
\hline 1 & $8.46 \pm 0.12$ & $16.1 \pm 1.3$ & $3.6 \pm 0.2$ & $1.5 \pm 0.2$ \\
\hline 2 & $8.34 \pm 0.13$ & $15.4 \pm 1.3$ & $3.6 \pm 0.2$ & $1.7 \pm 0.2$ \\
\hline 3 & $8.38 \pm 0.11$ & $21.8 \pm 1.4$ & $4.6 \pm 0.3$ & $2.0 \pm 0.2$ \\
\hline 4 & $8.42 \pm 0.10$ & $18.2 \pm 1.2$ & $5.3 \pm 0.3$ & $1.8 \pm 0.3$ \\
\hline
\end{tabular}




\begin{tabular}{|c|c|c|c|c|}
\hline \multirow{2}{*}{$\begin{array}{l}\text { Sample, } \\
\text { pond \# }\end{array}$} & \multirow[t]{2}{*}{$\mathrm{pH}$} & Monosilicic acid & Polysilicic acid & \multirow[t]{2}{*}{$\mathrm{x} 10^{5}$ cells $\mathrm{mL}^{-1}$} \\
\hline & & \multicolumn{2}{|c|}{$\longrightarrow$ Si, $\mu \mathrm{M} \longrightarrow$} & \\
\hline 5 & $8.43 \pm 0.11$ & $15.4 \pm 1.1$ & $4.3 \pm 0.2$ & $1.4 \pm 0.2$ \\
\hline 6 & $8.37 \pm 0.11$ & $17.1 \pm 1,3$ & $3.9 \pm 0.2$ & $1.5 \pm 0.2$ \\
\hline Average for ponds & 8.40 & $17.3 \pm 1.2$ & $4.2 \pm 0.1$ & 1.60 \\
\hline
\end{tabular}


Table 2

Abundance of microbial cells and silicic acid concentration after 3-day incubation, laboratory experiment.

\begin{tabular}{|c|c|c|c|c|}
\hline \multirow{2}{*}{ 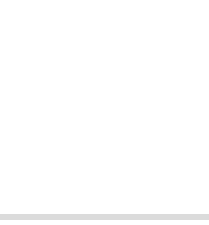 } & \multirow{2}{*}{$\mathrm{x} 10^{5}$ cells $\mathrm{mL}^{-1}$} & \multirow[t]{2}{*}{ Cell increase, \% } & \multirow{2}{*}{$\begin{array}{l}\text { Monosilicic acid } \\
-\mathrm{Si}, \mu \mathrm{M}-\end{array}$} & \multirow[t]{2}{*}{ Polysilicic acic } \\
\hline & & & & \\
\hline \multicolumn{5}{|c|}{ Sterile solution } \\
\hline Control & $n / d$ & - & $1.5 \pm 0.3$ & $0.1 \pm 0.1$ \\
\hline $\mathrm{Si}, 1 \mathrm{mM}$ & $n / d$ & - & $994.5 \pm 0.7$ & $0.3 \pm 0.1$ \\
\hline $\mathrm{Si}, 2 \mathrm{mM}$ & $n / d$ & - & $1983.5 \pm 1.5$ & $10.5 \pm 0.3$ \\
\hline \multicolumn{5}{|l|}{ Farm 1} \\
\hline Control & $2.1 \pm 0.1$ & - & $1.4 \pm 0.2$ & $0.2 \pm 0.1$ \\
\hline $\mathrm{Si}, 1 \mathrm{mM}$ & $2.5 \pm 0.1$ & 19.0 & $151.4 \pm 13.1$ & $15.3 \pm 0.7$ \\
\hline $\mathrm{Si}, 2 \mathrm{mM}$ & $2.9 \pm 0.2$ & 38.1 & $202.3 \pm 15.3$ & $47.5 \pm 0.9$ \\
\hline \multicolumn{5}{|l|}{ Farm 2} \\
\hline Control & $2.0 \pm 0.1$ & - & $1.2 \pm 0.2$ & $0.3 \pm 0.1$ \\
\hline $\mathrm{Si}, 1 \mathrm{mM}$ & $2.4 \pm 0.1$ & 20.0 & $142.3 \pm 10.1$ & $27.4 \pm 0.9$ \\
\hline $\mathrm{Si}, 2 \mathrm{mM}$ & $2.7 \pm 0.1$ & 35.0 & $183.3 \pm 10.3$ & $48.5 \pm 1.4$ \\
\hline \multicolumn{5}{|l|}{ Farm 3} \\
\hline Control & $1.5 \pm 0.1$ & - & $1.1 \pm 0.1$ & $0.2 \pm 0.1$ \\
\hline $\mathrm{Si}, 1 \mathrm{mM}$ & $1.9 \pm 0.2$ & 26.7 & $186.4 \pm 11.2$ & $18.4 \pm 0.5$ \\
\hline $\mathrm{Si}, 2 \mathrm{mM}$ & $2.4 \pm 0.2$ & 60.0 & $254.2 \pm 16.8$ & $57.5 \pm 0.8$ \\
\hline \multicolumn{5}{|l|}{ Ecopro } \\
\hline Control & $1.3 \pm 0.1$ & - & $0.3 \pm 0.1$ & $0.1 \pm 0.1$ \\
\hline $\mathrm{Si}, 1 \mathrm{mM}$ & $1.4 \pm 0.1$ & 7.7 & $755 \pm 45$ & $92 \pm 12$ \\
\hline $\mathrm{Si}, 2 \mathrm{mM}$ & $1.6 \pm 0.2$ & 23.1 & $1618 \pm 120$ & $133 \pm 21$ \\
\hline \multicolumn{5}{|c|}{ Ecopro Cold } \\
\hline Control & $1.2 \pm 0.1$ & - & $0.2 \pm 0.1$ & $0.1 \pm 0.1$ \\
\hline $\mathrm{Si}, 1 \mathrm{mM}$ & $1.4 \pm 0.1$ & 16.6 & $816 \pm 27$ & $25 \pm 1.5$ \\
\hline $\mathrm{Si}, 2 \mathrm{mM}$ & $1.6 \pm 0.1$ & 33.3 & $1633 \pm 127$ & $150 \pm 15$ \\
\hline
\end{tabular}




\begin{tabular}{|c|c|c|c|c|}
\hline & \multirow[t]{2}{*}{$\mathrm{x} 10^{5}$ cells $\mathrm{mL}^{-1}$} & \multirow[t]{2}{*}{ Cell increase, \% } & Monosilicic acid & Polysilicic acid \\
\hline & & & \multicolumn{2}{|c|}{$\longrightarrow \mathrm{Si}, \mu \mathrm{M} \longrightarrow$} \\
\hline \multicolumn{5}{|c|}{ HeJunMei } \\
\hline Control & $1.4 \pm 0.1$ & - & $0.4 \pm 0.1$ & $0.1 \pm 0.1$ \\
\hline $\mathrm{Si}, 1 \mathrm{mM}$ & $1.6 \pm 0.2$ & 14.3 & $833 \pm 32$ & $167 \pm 14$ \\
\hline Si, 2 mM & $1.8 \pm 0.2$ & 28.6 & $1770 \pm 125$ & $230 \pm 21$ \\
\hline
\end{tabular}

$\mathrm{n} / \mathrm{d}-$ not detected

Table 3

Reductions of monosilicic and polysilicic acids in pond water in comparison with those in the corresponding supply water, $\%$.

\begin{tabular}{|lllllll|}
\hline Pond, \# & \multicolumn{2}{l}{ Reduction, \% } & & & & \\
\cline { 2 - 5 } & $\begin{array}{l}\text { Monosilicic } \\
\text { acid }\end{array}$ & $\begin{array}{l}\text { Polysilicic } \\
\text { acid }\end{array}$ & $\begin{array}{l}\text { Monosilicic } \\
\text { acid }\end{array}$ & $\begin{array}{l}\text { Polysilicic } \\
\text { acid }\end{array}$ & $\begin{array}{l}\text { Monosilicic } \\
\text { acid }\end{array}$ & $\begin{array}{l}\text { Polysilicic } \\
\text { acid }\end{array}$ \\
\cline { 2 - 4 } & & Farm 2 & & Farm 3 & \\
\hline 1 & 98.3 & 66.4 & 80.0 & 65.0 & 67.3 & 63.4 \\
\hline 2 & 89.9 & 46.6 & 84.6 & 60.0 & 68.8 & 56.1 \\
\hline 3 & 97.4 & 73.3 & 87.2 & 50.0 & 55.8 & 43.9 \\
\hline 4 & 96.6 & 75.8 & 80.7 & 57.0 & 63.1 & 35.4 \\
\hline 6 & 97.5 & 46.6 & 85.0 & 46.0 & 68.8 & 47.6 \\
\hline Average & 96.2 & 57.6 & 88.6 & 36.0 & 65.3 & 52.4 \\
\hline
\end{tabular}


Table 4

Correlation coefficients $(\mathrm{R})$ between cell

abundance and soluble forms of $\mathrm{Si}$ in pond

water.

\begin{tabular}{|lll|}
\hline Farm \# & Monosilicic acid & Polysilicic acid \\
\hline 1 & 0.80 & 0.41 \\
2 & 0.83 & -0.87 \\
3 & 0.84 & 0.52 \\
\hline
\end{tabular}

Table 5

Changes in monosilicic and polysilicic acids in pond waters and probiotic solutions in comparison with the corresponding sterile solutions, \%.

\begin{tabular}{|lllll|}
\hline Solution & Si, $1 \mathrm{mM}$ & \multicolumn{3}{c|}{ Si, 2 mM } \\
\hline & Monosilicic acid & Polysilicic acid & Monosilicic acid & Polysilicic acid \\
\hline Farm 1 & -84.8 & +5000 & -89.8 & +352 \\
\hline Farm 2 & -85.7 & +9033 & -90.8 & +362 \\
\hline Farm 3 & -81.2 & +6033 & -87.2 & +447 \\
\hline Ecopro & -24.1 & +30567 & -18.4 & +2090 \\
Ecopro Cold & -17.9 & +8233 & -17.7 & +1328 \\
\hline HeJunMei & -16.2 & +55566 & -10.7 & +2090 \\
\hline
\end{tabular}

